\title{
Ein Film zum Thema
}

Auch zu dieser Illustration der Lotto-Gewinnwahrscheinlichkeiten gibt es einen kleinen Film. Er ist bei Youtube unter

<http: //www . youtube. com/watch?v=ODwm29lItOE >

zu finden und kann mit dem nachstehenden QR-Code aufgerufen werden.

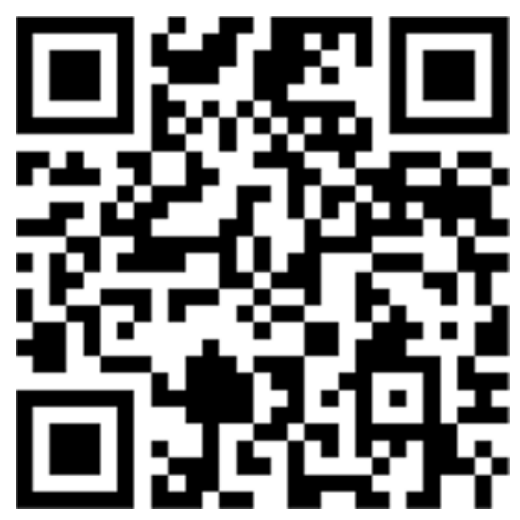

